\title{
Seeing and Tagging Things in Pictures
}

What men or gods are these? What maidens loth?

What mad pursuit? What struggle to escape?

What pipes and timbrels? What wild ecstasy?

-John Keats, "Ode on a Grecian Urn"

\section{Tagging Magritte}

ART UK, FORMERLY KNOWN AS Your Paintings, is an ambitious project to document and make accessible online all the paintings that are held by public museums in Great Britain. Launched at the National Gallery in June 2011, it was initially supported by the British Broadcasting Corporation and the Public Catalogue Foundation (now also renamed Art UK), a registered charity established in $2003 .{ }^{1}$ By August 2015, more than two hundred thousand paintings had been photographed for the project's database. ${ }^{2}$ Basic metadata for each painting was supplied by museum professionals, but more detailed metadata was crowdsourced by online volunteers, who "tagged" individual images with descriptive terms that could be entered in a search engine to call up relevant paintings. An interim history of the project noted that economy was a major incentive for the crowdsourcing: "It was obvious that it would be prohibitively expensive to pay expert fine art cataloguers to describe all 200,000 paintings systematically and that some sort of voluntary system would have to be devised." Crowdsourcing promised the contributing museums other benefits as well, including "the potential to engage both existing and new audiences," and the discovery of vernacular (rather than expert) search terms responsive to the interests of "the widest set of potential users." 3

\footnotetext{
A B S T RACT Despite modernist precepts, digital projects that use crowdsourcing to annotate large collections of images of paintings and book illustrations with "tags" have encouraged viewers to see things in pictures and to say what they see. Both personal image tagging (ekphrastic in function) and automatic image tagging challenge in different ways the proposition that a painting as such will elide recognizable content. RePRESENTAtions 155. Summer 2021 (C) The Regents of the University of California. ISSN 0734-6018, electronic ISSN 1533-855X, pages 82-109. All rights reserved. Direct requests for permission to photocopy or reproduce article content to the University of California Press at https://www.ucpress.110 edu/journals/reprints-permissions. DOI: https://doi.org/10.1525/ rep.2021.155.4.82.
} 
The technical infrastructure for Your Paintings Tagger was modeled on that of Galaxy Zoo, a crowdsourcing project that an international consortium of astrophysicists had launched in 2007 to classify photographic images of galaxies by type. Galaxy Zoo proved to be a surprising success, quickly enlisting thousands of volunteers to classify hundreds of thousands of galaxy images. ${ }^{4}$ At the end of 2009, that platform became Zooniverse, offering to host the crowdsourcing of large nongalactic data sets for other projects. ${ }^{5}$ The first such addition was soon launched (Solar Stormwatch); and by 2014 twenty sites were up and running. ${ }^{6}$ Most of the scores of Zooniverse projects that are now active, paused, or complete have to do with "citizen science" strictly speaking. However, two of them pertain to art history in different ways. AnnoTate, a project launched in 2015, has focused on documentary history; volunteers transcribe certain artists' personal papers in the collection of the Tate Archive. ${ }^{7}$ Fishing in the Past, launched in April 2020 and largely complete by January 2021, is a project more directly relevant to questions of visual representation. For that project, more than two thousand volunteers have proposed identifications of kinds of fish that are depicted in more than a thousand European oil paintings dating from 1550 to 1880; the results, concerning the distribution and consumption of different species at different places and times, will inform ichthyological and cultural history. ${ }^{8}$ The method (crowdsourcing the identification of things depicted in paintings) follows the pioneering work of Art UK, which, although not formally part of Zooniverse, is one of its oldest offspring and the most important crowdsourcing project in art history.

More than six million tags were entered into the Your Paintings Tagger system by volunteers; these were automatically aggregated and assessed by quantity and also quality-for which consistency is a proxy. Originally, at least fifteen taggers had to contribute to a tag set before it could be accepted; later that threshold was reduced somewhat. ${ }^{9}$ To gain acceptance, a particular tag had to be submitted by at least two contributors-except for the category "Types" (for example, Still life, Portrait), for which the threshold was four. (Investigation for a pioneer project, discussed later in the essay, had determined that museum staff found a tag to be "useful" 88.2 percent of the time when only one user proposed it; 96.8 percent of the time when two users concurred; and in every case when four or more users did so. ${ }^{10}$ When the tags assigned to a painting reached their assessment thresholds, they were added to the public search interface, enabling a user to find paintings tagged pipe, for example.

As of 25 June 2016, the Art UK website reported that the Tagger site had been "temporarily suspended" pending improvements to be made to the interface and the achievement of funding goals. ${ }^{11}$ The following account 
focuses on the project's original arrangements but also considers its later engagement with "artificial intelligence." 12

A Your Paintings tagger first responded to the open-ended question "What Things or Ideas can you see in this painting?" and then was asked to identify any "People," "Places," or "Events" depicted before being asked to choose a subject-matter label from a list and a genre ("Type") label from another list. ${ }^{13}$ To tag a painting with some care might take several minutes.

A "Frequent questions" page at the Your Paintings Tagger website addressed more than a dozen questions about the project. For example:

How does it work?

Each painting will be tagged many times by members of the public, and algorithms behind the scenes will calculate which tags are likely to be the most accurate. These tags will then be fed through to the Your Paintings website. The algorithms have been created for the Public Catalogue Foundation by the Citizen Science Alliance based at the Astrophysics Department at the University of Oxford, with input from the Art History Department at the University of Glasgow.

And:

What happens if I make a mistake?

Don't worry if you feel you have made a mistake. Many people will tag each painting and only the tags that the algorithm calculates are most likely to be the best answer will be used on the final Your Paintings website.

The most intriguing part of the catechism is this exchange:

Do I need to know anything about art?

No knowledge of art or art history is needed. Instead, all we ask is that you look carefully at the paintings and tell us what you see. ${ }^{14}$

Look carefully at the paintings and tell us what you see. For such a task some "knowledge of art or art history" might be inhibiting. To know René Magritte's painting La trahison des images is to discover that "what we see" is not what it seems to be: "Ceçi n'est pas une pipe" (fig. 1). Michel Foucault celebrated some of Magritte's drawings related to this painting for disrupting, as effectively as any abstract canvas by Wassily Kandinsky, received ideas or "principles" of "Western Painting... from the 15th to the 20th century," one of which "proposes the equivalence between the fact of similitude and the affirmation of a representative link."

That a figure should resemble a thing (or some other figure), that there should be a relation of analogy between them, is sufficient to assert in all our painting an obvious, banal, thousand-times-repeated and yet almost always silent statement (it is like an endless, haunting murmur which surrounds the figures' silence, invades it, 


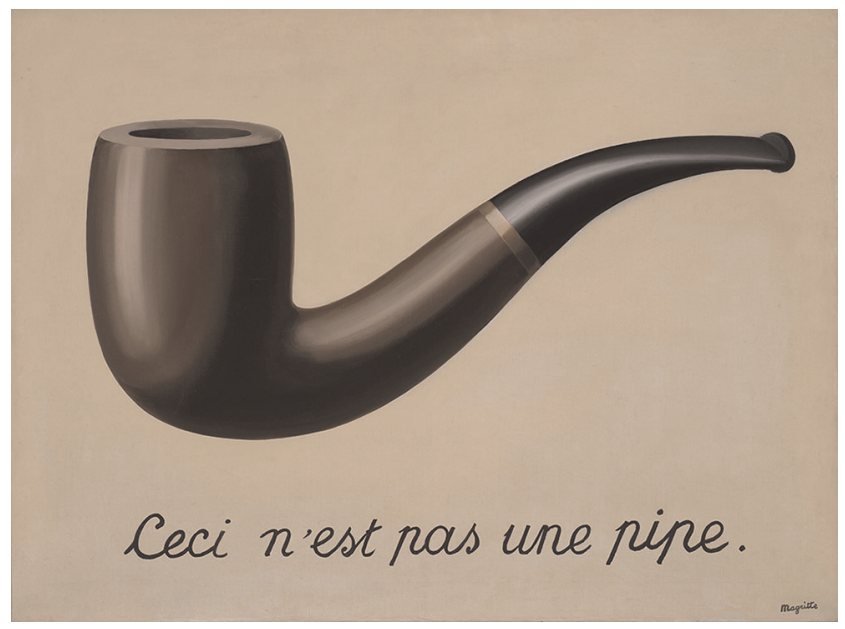

Figure 1. René Magritte, The Treachery of Images (This is Not a Pipe) (La trahison des images [Ceci n'est pas une pipe]). Oil on canvas. 1928. Los Angeles County Museum of Art. (C) 2021 C. Herscovici / Artists Rights Society (ARS), New York.

seizes, dispossesses, and finally shifts it into the realm of things we can name): "What you see, is that." 15

Magritte's Trahison subverts that silent statement. It would take some insouciance to tag this painting with the word pipe. Yet that indeed is what has been done at the website of the Los Angeles County Museum of Art (LACMA), which owns the painting and had it socially tagged, probably using an American prototype system called steve.museum, to which I will return. The full set of tags at the LACMA site reads (as of 17 January 2021): "misleading, irony, french, pipe, simple, surreal, writing, brown, black, tan." 16

Look carefully at the painting and tell us what you see. What someone sees, is that.

\section{Re-citing Matisse}

Almost as well known as the lesson of Trahison is the cautionary reply that Henri Matisse gave to a "lady" who, visiting his studio, criticized a painting because the arm of the woman that it depicted was too long: "Madame," he said, "you are mistaken: that is not a woman, that is a painting." 
This anecdote has been told many times, to illustrate the nonrepresentational, antimimetic quality of modern art, postmodern art, and, sometimes, all art. E. H. Gombrich told the story twice in Art and Illusion: A Study in the Psychology of Pictorial Representation, a landmark account of pictorial mimesis and its technical history. Each time he told the story he gave it a summative significance.

In early editions of that book, Gombrich told the story to conclude his account of ancient beliefs about the power of art, such as the myth of Pygmalion, which would ascribe to the artist the full power of poesis-a godlike power of creation that unfortunately entailed a magical curse. The antidote to such hubris was the Matisse anecdote:

We may have made quite a good bargain when we exchanged the archaic magic of image making for the more subtle magic we call "art." For without this new category of "pictures," image making would still be hedged in by taboos. Only in the realm of dreams has the artist found full freedom to create. I think the difference is well summed up in the anecdote about Matisse. When a lady visiting his studio said, "But surely, the arm of this woman is much too long," the artist replied politely, "Madame, you are mistaken. This is not a woman, this is a picture." 17

Gombrich refers to this as "the anecdote about Matisse," suggesting that it was already in circulation and might be recognized; but in a note he documents a somewhat different version-what he called "the master's own version of the anecdote," written for the literary and artistic review Le Point in 1939: "J'ai répondu à quelqu'un qui disait que je ne voyais pas les femmes comme je les représentais: $\mathrm{Si}$ j'en rencontrais de pareilles dans la rue, je me sauverais épouventé. Avant tout, je ne crée pas une femme, je fais un tableau." ${ }^{18}$ In his collection of the artist's writings, Matisse on Art (1973), Jack D. Flam translated this passage as follows, supplying also the previous sentences: "Someone called me: 'This charmer who takes pleasure in charming monsters.' I never thought of my creations as charmed or charming monsters. I replied to someone who said I didn't see women as I represented them: 'If I met such women in the street, I should run away in terror.' Above all, I do not create a woman, I make a picture." 19

In a note to this passage, Flam identifies the "someone" in both instances as Gertrude Stein, although he does not explain why (167n6). (In the revised edition of 1995 he reassigns the first mention of "someone" to someone else, and drops the Stein reference even for the second.) ${ }^{20}$ Stein, of course, was one of Matisse's most important early patrons. Although this version of the anecdote would cast her at least for the moment as a critic of his vision of art, she generally shared his ambition to free painting from representational obligations. Gustave Courbet's realist landscapes, admittedly premodern but also protomodern, presented a difficult 


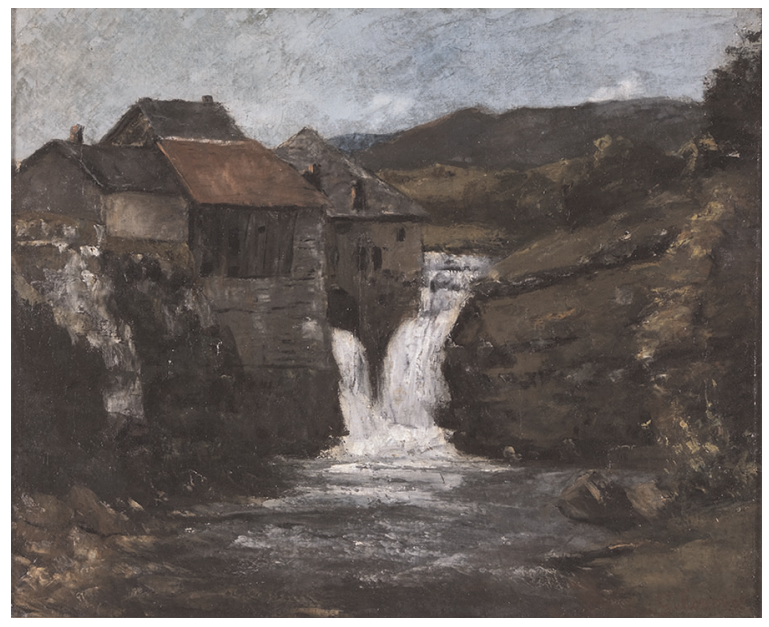

FIgure 2. Gustave Courbet, The Mill at Orbe. Oil on canvas. 1875. (C) Amgueddfa Cymru-National Museum of Wales. Photo credit: National Museum of Wales.

case: looking so much like nature, could they be art? She worried that question in Lectures in America (1935):

Courbet bothered me. He did really use the color that nature looked like that any landscape looked like when it was just like itself as you saw it in passing. Courbet really did use the colors that nature looked like to anybody, that a water-fall in the woods looked like to anybody.

And what had that to do with anything, in fact did it not destroy a little of the reality of the oil painting. The paintings of Courbet were very real as oil paintings, they existed very really as oil painting, but did the colors that were the colors anybody could see trees and water-falls naturally were, did these colors add or did they detract from the reality of the oil painting as oil painting. Perhaps and most likely perhaps it did not really make any difference. There was a moment though when I worried about the Courbets not being an oil painting but being a piece of country in miniature as seen in a diminishing glass.... But soon I concluded that no, it only seemed so, no the Courbets were really oil paintings with the real life of oil paintings as oil paintings should have. Only the Courbets being nearly something else always keeps them from being really all they are. ${ }^{21}$

If Stein were to tag Courbet's The Mill at Orbe (fig. 2) for Your Paintings, she would have to resort to words such as "mill," "waterfall," "tree," and "mountain," and she would feel uncomfortable about the whole business.

Gombrich renewed his Matisse anecdote at the end of the preface, titled "Images and Signs," that he wrote for the final edition of Art and Illusion. ${ }^{22}$ This time the foil to mimesis was not poesis à la Pygmalion but semiosis à la 
Nelson Goodman; for in 1968 that philosopher had launched an influential argument that images were not (as Gombrich thought) a matter of constructed resemblance but rather of code, very much like language, and so should be addressed within semiotic theory. ${ }^{23}$ Such views became a new orthodoxy, and Gombrich dissented from it in an essay he published in 1981, "Image and Code: Scope and Limits of Conventionalism in Pictorial Representation." 24 Most of the new preface to Art and Illusion renews his critique of a merely semiotic account of picturing. Near the end, however, he shifts the argument from the philosophy of representation to its history. Evidently photography had usurped the mimetic function of art, causing painters to embrace a nonmimetic, modernist formalism- a formalism that was akin to code. In a crisp, if surprising, sports metaphor he remarks, "as soon as Daguerre's and Fox Talbot's mechanical methods entered the field, art had to shift the goalposts" (xxxv). The move was a defensive one, provoked by the representational power of photography. Then, a final paragraph:

An anecdote about Matisse which I quote in Art and Illusion, sums it all up. When a lady, looking at one of his portraits, told him that the arm of the woman was too long, he replied: "Madam, you are mistaken, this is not a woman, this is a painting." No wonder Matisse's contemporary, the art dealer Daniel Kahnweiler, wrote that paintings should be seen as signs, and not as illusory objects. (xxxv)

Again, this vivid anecdote "sums it all up"; but all it sums up is the retreat to modernism. To account for the progressively representational art of the previous centuries, Gombrich implies, one needs to read the rest of Art and Illusion.

The idea that photography drove painters to abstraction dates back several decades before Gombrich. "The camera has done much to oust painting from its position as an art of representation," observed Charles H. Caffin, specifically apropos Matisse, in his popular primer How to Study the Modern Painters (1914). "Matisse has no interest in the use of painting as a means of representing the external appearances of life and nature. He has no desire to compete with the camera." ${ }^{25}$ (Caffin had earlier remarked that Matisse found photography to be merely a useful tool for the artist and not an art in itself.) ${ }^{26}$

Where did Gombrich come upon his favored anecdote, which he evidently knew before Matisse published his own "version" in Le Point? He does not say, but a possible source was John Dewey, who, in Art as Experience (1934), endorsed some aspects of l'art pour l'art as they had been articulated by A. C. Bradley in "Poetry for Poetry's Sake," his inaugural lecture as professor of poetry at the University of Oxford (1901). ${ }^{27}$ Dewey follows Bradley in distinguishing the mere referential "subject" of art from its 
FIGURE 3. Vincent van Gogh, A Pair of

Shoes. Oil on canvas. 1886. Van Gogh

Museum, Amsterdam (Vincent van

Gogh Foundation).

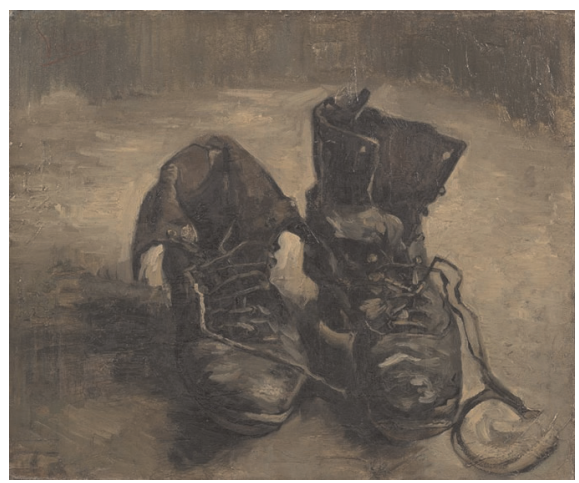

wrought "substance." Works of art are things in themselves, not reminders of something else. According to Dewey, Matisse's rebuke is exemplary:

"Madam, that is not a woman; that is a picture." The critics who drag in extraneous subject-matter-historical, moral, sentimental, or in the guise of established canons that prescribe proper themes-may be vastly superior in learning to the guide in the gallery who says nothing about paintings as pictures and a great deal about the occasions which produced them and the sentimental associations they arouse, the majesty of Mount Blanc or the tragedy of Anne Boleyn; but esthetically they stand on the same level. ${ }^{28}$

In this satire the art critic or the gallery guide may not quite descend to tagging the Things they see in a painting, but they do say "a great deal" about the Ideas—-"the sentimental associations they arouse"-which seems as bad, or even worse.

Dewey's guide in the gallery, dispatched with just a few words, will return half a century later to suffer the elaborate scorn of Jacques Derrida, a different kind of philosopher who yet shared Dewey's modernist impatience with mere representation. The errant guide this time is Martin Heidegger, who had waxed enthusiastic about the rural virtues implied by a Van Gogh painting of a pair of shoes (fig. 3). Derrida objects to "the massive self-assurance of the identification: 'a pair of peasants' shoes,' just like that! Where did he get that from? Where does he explain himself on this matter?" 29 Evidently, image tagging requires scrupulous justification. And then Derrida imposes an extended metaphor, in which Heidegger is a tedious, sentimental gallery guide, who "piles up the associations and immediate projections. From time to time he points out of the window to the fields and nobody notices that he's no longer talking about painting." Bad enough, perhaps; but 


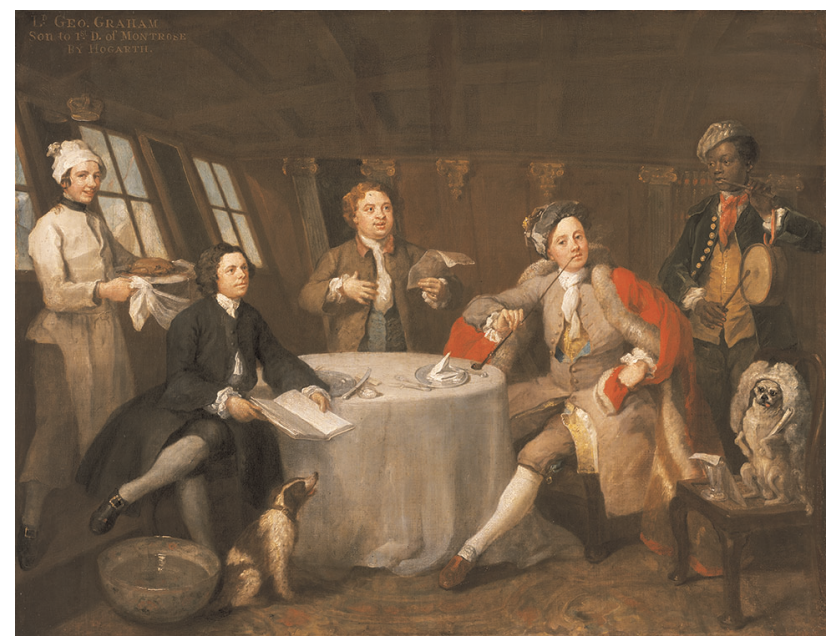

FIGURE 4. William Hogarth, Captain Lord George Graham, 1715-47, in His Cabin. Oil on canvas. 1742-44. (C) National Maritime Museum, Greenwich, London.

Heidegger's first failing in this gallery, which Derrida remarks at the outset, is his "consumerlike hurry toward the content of a representation" (292).

\section{Pre-iconography, Photography}

Is it wrong to for a philosopher, critic, or gallery guide to "tag" a painting as if it were a documentary photograph? Although modernist formalism took on an imperial reach and cast a wide net, catching Courbet and other artists before him, it is hard to appreciate a William Hogarth painting such as Captain Lord George Graham in His Cabin, 1715-47 (174244; figs. 4 and 5) without noticing things such as the large clay pipe near the center of the picture. And there are other things to tag there: cabin, window, dog, wineglass, wig, gravy, Chinese bowl, table, tablecloth, book, paper, drum, fife, not to mention the persons and their articles of clothing. Hogarth scholarship must see such things, and so Ronald Paulson, the dean of Hogarth scholars, mentions many of them in his brief accounts of the painting. ${ }^{30}$

And now we are asked to see and say such things for representational paintings in general. The pioneer project for such work, which served as a model for Your Paintings Tagger, was called "steve," also known as "steve.museum." Sponsored by a consortium of museums in the United States from October 2006 to December 2008, it investigated how crowdsourced tagging of object images might enhance curatorial metadata and 


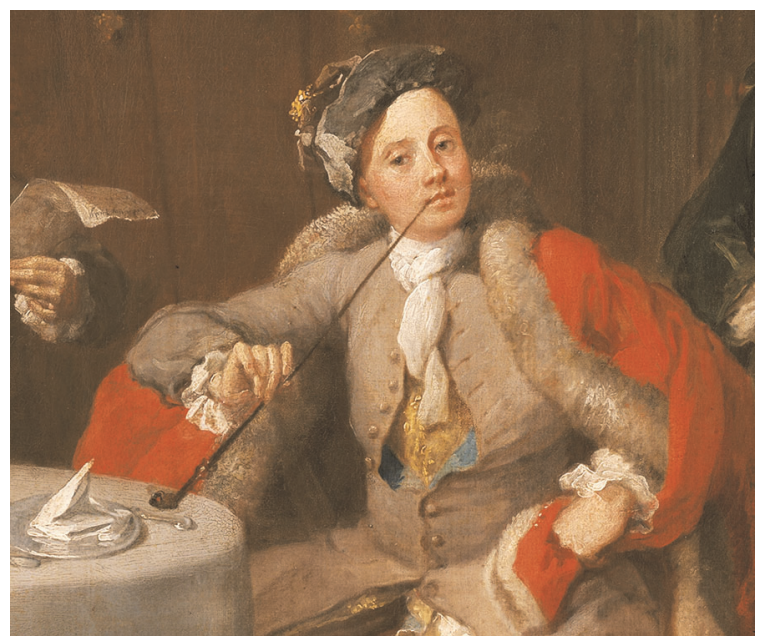

Figure 5. Detail of figure 4. (C) National Maritime Museum, Greenwich, London.

improve institutional outreach. Jennifer Trant, the principal investigator, published a final report in January 2009, and several participant institutions launched crowdsourced tagging initiatives for items in their collections. ${ }^{31}$ The works tagged by volunteers during the trial ranged across media types, with paintings constituting the largest share, though not a majority (35.8 percent). Prints, photographs, and drawings and watercolors added 4.4, 5.6 , and 5.3 percent respectively. In other words, only half of the objects that were photographed for tagging were two-dimensional images; the others were pieces of sculpture, "decorative arts and utilitarian objects," "costume and jewelry," and the like (14). Some consideration was given to presenting items of a similar type in sequence, to prevent "the jarring sense of seeing a nonrepresentational contemporary painting right after a classical sculpture" (81). "It did appear... that showing unrelated works in random order was the least effective presentation" (91). The general question of representational painting versus nonrepresentational painting was not explored in the report, although images were coded in the database with the numeral 1 "if object depicted is representational (not abstract)" (Appendix I-13). In such a case, a painting that depicted a pipe might be tagged pipe. (That the word "pipe" is ambiguous as regards fluids, music, or tobacco is a fault of language, not of pictures.) This is (a picture of) a woman, and might be tagged woman. (Indeed, in the trial set the most common tag was woman [32].) That it is a picture goes without saying: no need to tag it picture. (However, tags identifying the medium would be informative and therefore helpful: painting, oil on canvas—or Stein's essential term, oil painting:) 
When Judith L. Klavans and others later analyzed subject-matter categorization in the steve.museum project they focused on a hundred "images of two-dimensional, representational paintings" from that collection, excluding "images of an abstract nature," because a standard framework for image cataloging was "designed for representational images." 32 They noted that taggers of representational images paid relatively little attention to "visual elements" (color, texture, outline, and the like), focusing their attention instead on aspects of subject matter (8). Evidently such behavior ignored Stein's preferences and fulfilled Foucault's bleak prediction.

A standard that Klavans and her colleagues drew upon for their analysis, which was designed by Sara Shatford in 1986 and is sometimes called the Shatford-Panofsky matrix, elaborates to a set of twelve facets the three basic categories that Erwin Panofsky defined in 1939, in the introduction to his influential treatise Studies in Iconology: "pre-iconographical," "iconographical," and "iconological." 33 According to Panofsky the pre-iconographical category concerns "Primary or Natural Subject matter, subdivided into factual and expressional."

It is apprehended by identifying pure forms, that is: certain configurations of line and colour, or certain peculiarly shaped lumps of bronze or stone, as representations of natural objects such as human beings, animals, plants, houses, tools and so forth; by identifying their mutual relations as events; and by perceiving such expressional qualities as the mournful character of a pose or gesture, or the homelike and peaceful atmosphere of an interior. The world of pure forms thus recognized as carriers of primary or natural meanings may be called the world of artistic motifs. An enumeration of these motifs would be a pre-iconographical description of the work of art. $^{34}$

It is mostly these aspects of a painting that the Your Paintings Tagger would inventory: represented objects ("Things" in the Tagger catechism), "expressional qualities" ("Ideas"), and events ("Event"). However, "things" and "ideas" are sufficiently ambiguous terms to embrace also data from Panofsky's second category, "Secondary or Conventional Subject matter," the domain of iconography (6); or even from his third, "Intrinsic Meaning or Content," the domain of iconology (7). Still, most volunteered tags will involve pre-iconographical things or ideas. Despite Dewey and Matisse, one must start somewhere.

A relevant starting place for all these investigations is the late history of photography. If the representational prowess of that new invention prompted painters to retreat from representation, it soon also fostered the academic discipline of art history by representing artworks in shareable, published photographs. ${ }^{35}$ Now, in the twenty-first century, digital photography is everyone's representational tool. Few people can draw, but everyone can photograph, and everyone sees in photographs things that can be 
named. The pioneering website Flickr made it easy not only to share personal photographs but also to tag them with specific identity informationinformation that Panofsky would assign to the second stage of description, iconographical. Before long, more than a hundred institutions, including the Library of Congress and the British Library, made use of the Flickr Commons infrastructure to publish thousands of photographic images to be tagged, many of them images of works of art. ${ }^{36}$ Some of these taggable images had been created in the first place as photographs; however, regardless of the original medium, whether painting, drawing, print, or sculpture, all works of art had to become digital photographs to enter the Commons. Such clearing houses of public photography encouraged not a modernist tact but a naive realism, premodern or (at least in the chronological sense) postmodern: not a seeing of the picture but a seeing of the woman there. "All we ask is that you look carefully at the paintings and tell us what you see."

\section{Tagging as Ekphrasis}

According to Ruth Webb, ekphrasis was an obscure term in classical rhetoric, denoting vivid description in general (not necessarily of art objects), until it entered the English critical vocabulary in the 1950s with the publication of Leo Spitzer's article "The 'Ode on a Grecian Urn,' or Content vs. Metagrammar." ${ }^{37}$ Early on, Spitzer briefly remarked that John Keats's poem "belongs to the genre, known to Occidental literature from Homer and Theocritus to the Parnassians and Rilke, of the ekphrasis, the poetic description of a pictorial or sculptural work of art" (206-7). Later, he reminded the reader that "the ekphrasis [is] the description of an objet d'art by the medium of the word" (218). A fuller account, and wider publicity for the term ekphrasis, would come with the publication in 1960 of "Ekphrasis and Aesthetic Attitudes in Vasari's Lives," by Svetlana Leontief Alpers-an article that began life under the supervision of E. H. Gombrich, "in whose seminar at Harvard [it] was begun and whose valuable suggestions and constant interest enabled it to progress," and that eventually found an influential forum in the Journal of the Warburg and Courtauld Institutes. ${ }^{38}$

Focusing on Giorgio Vasari's many descriptions of particular paintings in Le Vite de' più eccellenti pittori, scultori e architetti (Florence, 1550), Alpers characterizes them as exercises in "the rhetorical figure of ekphrasis" - that is, "verbal evocations of actual paintings," also referred to as "the traditional device of ekphrasis" (191). Vasari's descriptions are richly, if selectively detailed, and "the picking out of details is part of the ekphrasis tradition" 
(194-95n21). As Vasari reads Leonardo da Vinci's Last Supper, for example, the verisimilitude with which the tablecloth is rendered offsets the vividness with which the faces of the apostles display diverse emotions-love, fear, anger, sorrow (193). Alpers cautions that such selective description tends to be controlled by narrative preconceptions ("commonplaces"), sometimes even projecting onto the painting details that are not to be found there, although they figure outside the painting in an associated narrative. "Looking at art and describing what he saw legitimately involved for Vasari what we today might think of as 'reading in'" (194-95).

Webb objected that the ekphrastic tradition to which Alpers refers was no such thing, and that in recent decades the word ekphrasis has been used with a protean casualness. "In the absence of an agreed definition, apart from the broadest 'writing on art,' each critic is able, effectively, to redefine the term to suit his or her interests and to fit the corpus of works chosen as representative" (17). So be it. Today it is hard not to contemplate the many tags being volunteered for pictures as composing a communal ekphrasis, necessarily different, imperfect, fragmentary in its attention to selected details, yet worthy of attention and even respect; as, for example, apropos Magritte's La trahison des images, "misleading, irony, french, pipe, simple, surreal, writing, brown, black, tan."

\section{Tags as Graffiti}

The word "tag"—noun and verb— traces back to Middle English. At first denoting a pendant fragment or ribbon of clothing, it came to mean an appendage generally, and then an appended label—eventually just becoming synonymous with "label." In the 1940s the word was used to name a part of computer code that labeled a particular piece of data, enabling cross-reference. ${ }^{39}$ When the del.icio.us social-bookmarking site launched in 2003, the word "tag" was used as a matter of course to refer to a distinctive and accessible bookmark label. Not long after the founders of Flickr launched their photo-sharing site in 2004, they followed that lead to enable photo "tagging." As Eric Costello, an early developer, recalled in 2006:

Tags were not in the initial version of Flickr. Stewart Butterfield [a founder] wanted to add them. He liked the way they worked on del.icio.us.... We added very simple tagging functionality, so you could tag your photos, and then look at all your photos with a particular tag, or any one person's photos with a particular tag.

Soon thereafter, users started telling us that what was really interesting about tagging was not just how you've tagged your photos, but how the whole Flickr community has been tagging photos. So we started seeing a lot of requests from users to be able to see a global view of the tagscape. ${ }^{40}$ 
"The tagscape" soon became a feature of the photo archives of institutions as well as persons. As has already been mentioned, the success of Flickr gave rise to The Commons, a multi-institutional social image-tagging site that was launched in 2008, pioneered by the Library of Congress. Your Paintings entered the tagscape three years later, on 23 June $2011 .{ }^{41}$

Costello's comments, at this point and later in his interview, recognize how tagging can be at once personal and social, egocentric and informational. They do not register the fact that the personal, expressive side of "tagging" came to the fore in quite a different, older context-the world of graffiti. Since the 1980s the most personal form of graffiti has been called a "tag" - a self-label, a stylized signature ${ }^{42}$ Rarely singular, tagging is repetitive, reproductive, akin to spam in that respect, but usually better designed, more stylized, more stylish, more attractive, more an object of display, and sometimes even creditable - and taggable - as a work of art. ${ }^{43}$

The hazard in socially tagging works of art online is that such tagging, necessarily self-expressive to some extent (like graffiti tagging in the world), may fail to inform about anything other than the style of the self, slighting "the object as in itself it really is." ${ }^{44}$ As this quotation from Matthew Arnold's much-rehearsed slogan acknowledges, such a hazard is not new, only the medium is. So Dewey, in Art as Experience, again following A. C. Bradley (just before the passage discussed earlier), dreads the self-absorption of the gallerygoer who sees on the wall only his idiosyncratic concerns or received ideas, ignoring the work of art itself:

Mr. Bradley calls attention to the common tendency to treat a work of art as a mere reminder of something, by the illustration of the sight-seer in a picture-gallery who remarks as he moves along, "This picture is so like my cousin," or that picture "the image of my birthplace," and "who, after satisfying himself that one painting is about Elijah, passes on rejoicing to discover the subject and nothing but the subject of the next one." 45

Yes, recognize the "subject," but pay more attention to the "substance"and just forget about the cousin and the birthplace. Presumably the Your Paintings Tagger algorithm would favor the iconographic tag (Elijah) and discard the private projection: the eccentric response, the outlier tag, the unique ekphrastic gloss.

\section{Tags Latent and Patent}

Tags can serve several functions. Although they mainly enable searching on a term and thus provide access to an image of a relevant painting, they will also, if displayed near the image, direct the viewer's attention to something to see in the painting and may even link to other 


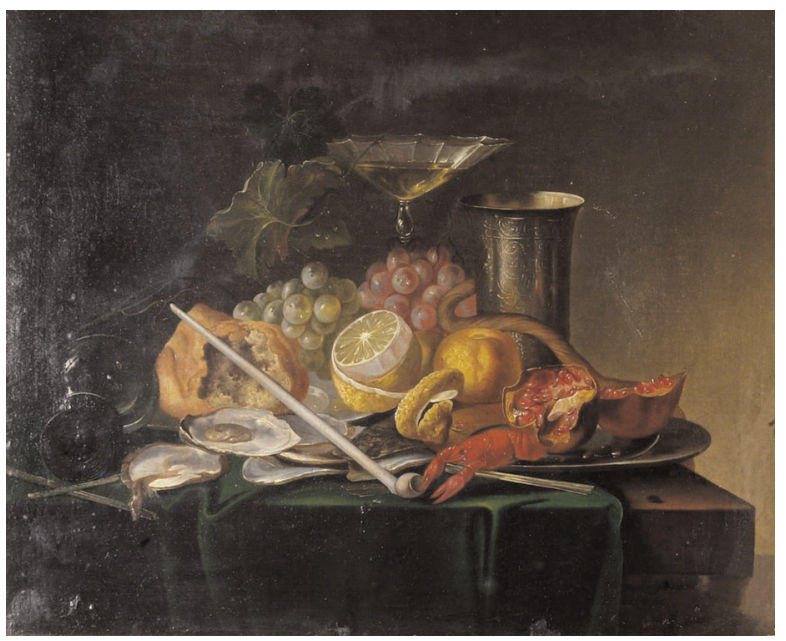

Figure 6. V. Schut [or v. Schut], Still Life with a Lobster and Oysters. Oil on canvas. Circa 1850(?). Craven Museum and Gallery, Roebuck Collection, Skipton. Photo credit: Craven Museum and Gallery. Licensed under CC BY-NC-ND.

paintings that are similarly tagged. Like any form of annotation or commentary, a displayed cluster of tags will bias attention in certain directions; if some aspects are noticed, others, perhaps equally noteworthy, will be ignored. A case in point is the cloud of tags that hovers at Art UK below the image of Still Life with a Lobster and Oysters, an oil painting credited to "V. Schut," which is said to have been made around 1850 (fig. 6). ${ }^{46}$ It was bequeathed by Clement Roebuck to the Craven Museum and Gallery, Skipton, North Yorkshire, in 1988. These were the tags, thirty-one altogether, that Your Paintings displayed for this painting in September 2015:

Food, Fruit, Knife, Orange, Grapes, Platter, Grape, Vase, Goblet, Table, Still Life, Tablecloth, Plate, Wine, Silver, Vine, Lemon, Glass, Pomegranate, Oysters, Shell, Oyster, Lobster, Bread, Pipe, Clay Pipe, Wine Glass, Smoking Pipe, Crayfish, Oystershell, Still life. ${ }^{47}$

These tags appear to be in no particular order; they may be sequenced as they were first entered by taggers. The co-occurrence of Still Life and Still life may reflect options that were available to the tagger in the separate categories "Things" and "Painting Types." A more ordinary duplication involves singular and plural: we have both Oyster and Oysters, Grape and Grapes. ${ }^{48} \mathrm{On}$ the other hand, we have Knife but not Knives: one knife shows its blade at the lower left, but the other, laid across it, is partly obscured and goes unnoticed. Shell and Oystershell are two ways of naming (in this case) the same 


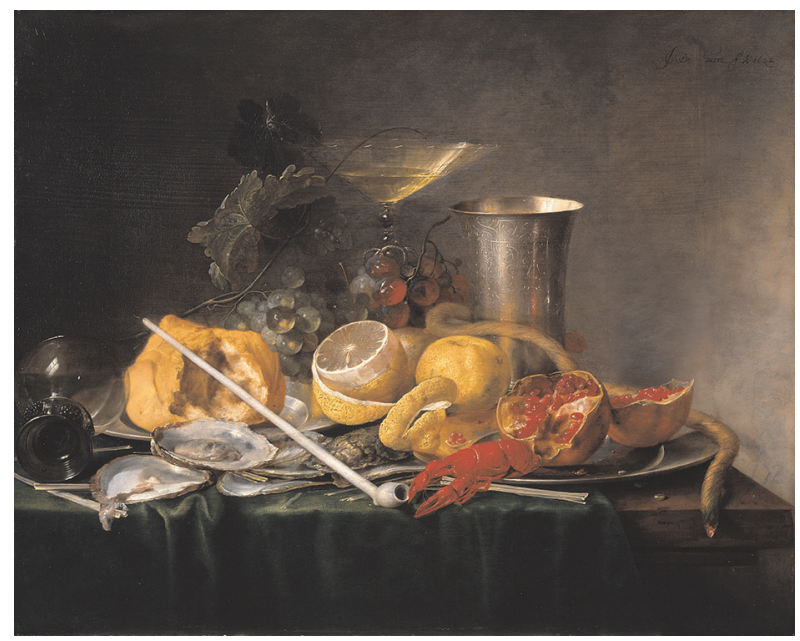

Figure 7. Jan Davidsz. de Heem, Still Life, Breakfast with Champaign Glass and Pipe. Oil on oak panel. 1642. Residenzgalerie, Salzburg.

Things; and again the objects are plural, not singular. Pipe, Clay Pipe, and Smoking Pipe are three labels for only one Thing. Lobster and Crayfish are competing terms for the same imaged Thing: which is it? Glass and Wine Glass are the same Thing; or is it Glass and (glass) Goblet (resting on its side, to the left)? And is that really a Vase to the right? Or something else? And why no mention of that large green leaf in the upper left? Perhaps a grape leaf? The Vine does get tagged. And what is that long, twisted brown Thing draped from the center over the right edge of the table? Fairly conspicuous, but unidentified.

The attribution of this painting to "V. Schut" by Your Paintings (now by Art UK), and the dating of it as "c. 1850," both follow the entry in a published catalog, which gives a variant title, Still Life with Grapes, Oysters, a Lemon and Pomegranates on a Draped Table ${ }^{49}$ Describing the painting for a later project, Lisa Howard assigned it to the seventeenth century (estimating a range from 1630 to 1700 ), which does seem more likely. ${ }^{50}$ She placed "Schut, V." as a "Dutch artist, active 17th century." She also reported the inscription, lower right, as "v. Schut"-which suggests that the painter was van Schut, not V. Schut. Neither name is readily identifiable. (However, the signature "v. Schut" figured also on a similar painting that was sold at auction in 2015.) ${ }^{51}$

Whoever did paint Still Life with a Lobster and Oysters, and whenever, the result looks to be a close copy of Still Life, Breakfast with Champaign Glass and Pipe, a painting that Jan Davidsz. de Heem painted in 1642, which is now housed in the Residenzgalerie, Salzburg (fig. 7). In a catalog entry, after 
describing many of the luxurious and sensuous attractions that this still life displays, Thomas Habersatter notes that they are all ironized by vanitas symbols: "the glowing fuse, the pipe... the overturned rummer." 52 The glowing fuse is the brown cord draped around the silver beaker (not a Vase) and the pomegranate sections next to it. The fuse appears also in the Craven Museum painting, but was not tagged. Admittedly the fuse is more conspicuous in the de Heem original, draped as it is over the front of the table, with a lit end glowing in full view, close to the picture plane and set off against the dark edge of the table. Originally used to fire guns, such match-cords were also used to light pipes. The same motif figures in other Dutch paintings of the period. ${ }^{53} \mathrm{~A}$ textbook precedent is the rapidly burning fuse shown in plate 24 of Roemer Visscher's emblem book Sinnepoppen (Amsterdam, 1614), where it symbolizes the evanescence of all things.

Symbolism is not just a layer of meaning on top of a thing, but a motive for putting the thing there and also for noticing it. Someone alert to vanitas imagery is more likely to notice the fuse in the Craven Museum painting. Some things that we see in pictures we see because we see they signify. Despite the assurances of the Your Paintings Tagger FAQ, it helps to know something about art history just to see some Things in paintings. Or, symbolism and art history aside, it helps just to know something about history. To see a brown cord as a fuse, a tool that can be used to light a pipe, it helps to know that Dutch smokers once lit their pipes with such things. Knowing about such things helps to see them at all. "All seeing is seeing-as" may be an overstated maxim, but it is not vacuous. ${ }^{54}$ "What you see, is that": what you see, you see as something.

\section{Cloudy Tags}

What is seen can also be said, more or less. All commentary is partial commentary, but the commentary of a cluster of tags, whether weighted or not, is especially likely to be incomplete, and to be awkward in its incompletion. Consider, for example, the verbal cubism of this cluster: "misleading, irony, french, pipe, simple, surreal, writing, brown, black, tan." With their blunt statement and sharp elbows, these faceted terms rather obscure than reveal the content of Magritte's painting. As target terms and finding aids they would function well enough behind the scenes, bringing the user who wanted to see a painting of a pipe, or just something brown, to contemplate this painting among others. However, if such tags were presented as descriptive, they would be literally prejudicial, preprocessing the picture in advance of any contemplation. Describing something is different from issuing a search inquiry (a representative speech act, not a directive, in 


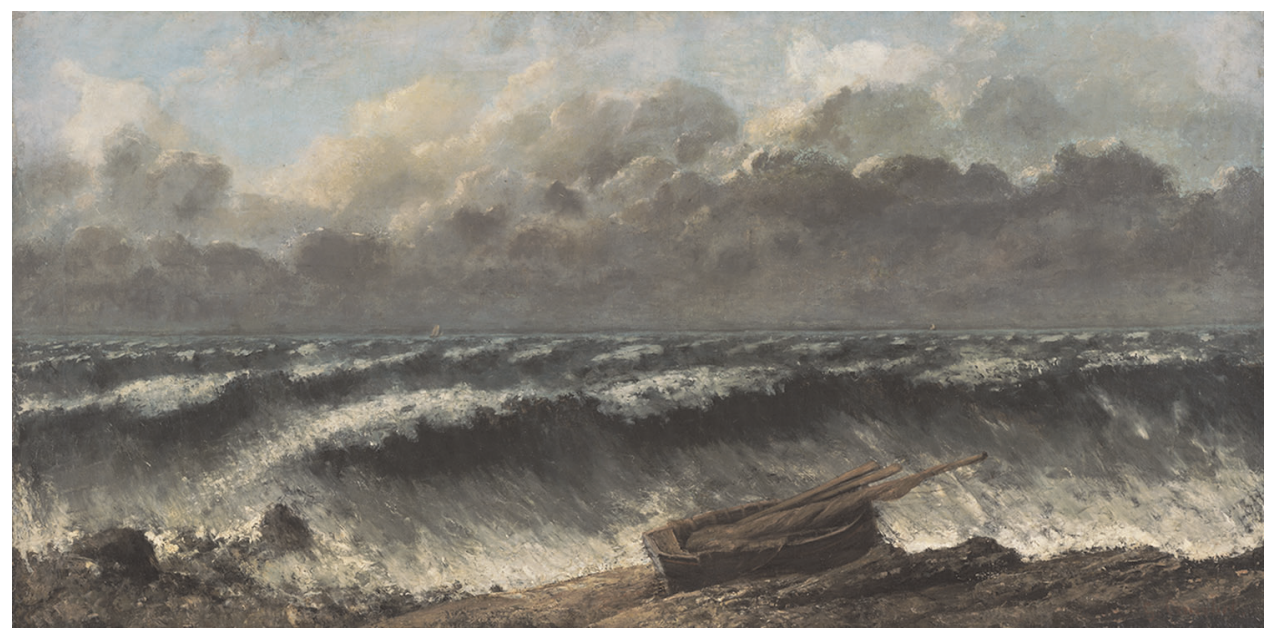

Figure 8. Gustave Courbet, Waves. Oil on canvas. 1869. Philadelphia Museum of Art: Gift of John G. Johnson for the W. P. Wilstach Collection, 1905, W1905-1-1.

John Searle's terms); therefore describing is subject to a different kind of assessment. ${ }^{55}$ The first submaxim of Paul Grice's "Maxim of Quantity" applies here: "Make your contribution as informative as is required (for the current purposes of the exchange)." 56 In such cases less is not more; the display of a limited tag set will be reductive. Better, then, to leave the tags latent, not patent, responsive to search but not by default on display as a description; something, rather, that can be toggled on by choice. That is how LACMA arranges matters in this case, as in others (although for many, if not most, other paintings the report is, "This item has not been tagged yet"). Better, that is, unless a purpose for the image-tagging system is to enlist and reward (with the display of such tags) participation from members of the public as a way of extending institutional outreach: "networking and community building" in the words of one review article; "engaging the public" as Andrew Greg put it in the title of his 2014 presentation at the University of Edinburgh. ${ }^{57}$ If tags are to be sought from the public, an overt display of tags that have already been accepted for a painting can strengthen the invitation to add a tag. So, on 28 January 2021, the web page at the Philadelphia Museum of Art that displayed an image of Courbet's oil painting Waves (1869; fig. 8) also displayed, directly below it, the following tag set, above a link that read Add Your Own Tags:

beach $[\mathrm{x}]$ coast $[\mathrm{x}]$ overcast $[\mathrm{x}]$ realism $[\mathrm{x}]$ rowboat $[\mathrm{x}]$ seascape $[\mathrm{x}]$ seaside $[\mathrm{x}]$ storm $[\mathrm{x}]$ violent $[\mathrm{x}]$ waves $[\mathrm{x}]^{58}$ 
Conveniently, each of these tags was hyperlinked, enabling quick access to images of other paintings bearing the same tag: 118 other images in the case of beach. Unusually, the Philadelphia Museum website included an " $[\mathrm{x}]$ " link next to each posted tag, which anyone could use to delete it, after responding positively to the cautionary query, "Are you sure that you want to delete this?" Yes for dark, french, and tides. ${ }^{59}$ Apparently no one tagged this painting oil painting, which would have been Stein's preference, unclouded by all the other distracting terms.

The austerity of Stein's gaze, averted from representational content in paintings, has its modern counterpart in the tact with which a museum may choose not to display a tag set at all. The web page at the Indianapolis Museum of Art for Georges Lemmen's The Two Sisters or the Serruys Sisters shows no tags (as of 19 January 2021): just an image of the painting (zoomable to display the pointillist technique in remarkable detail), a curator's note (including tabbed entries for "Gallery Label," "Related Text," and "Provenance"), some "Object Information," and a half dozen smaller images of paintings that, a heading suggests, "You May Also Like." The top of the page is particularly discreet, showing the image alone against a white

\section{THE TWO SISTERS OR THE SERRUYS SISTERS}

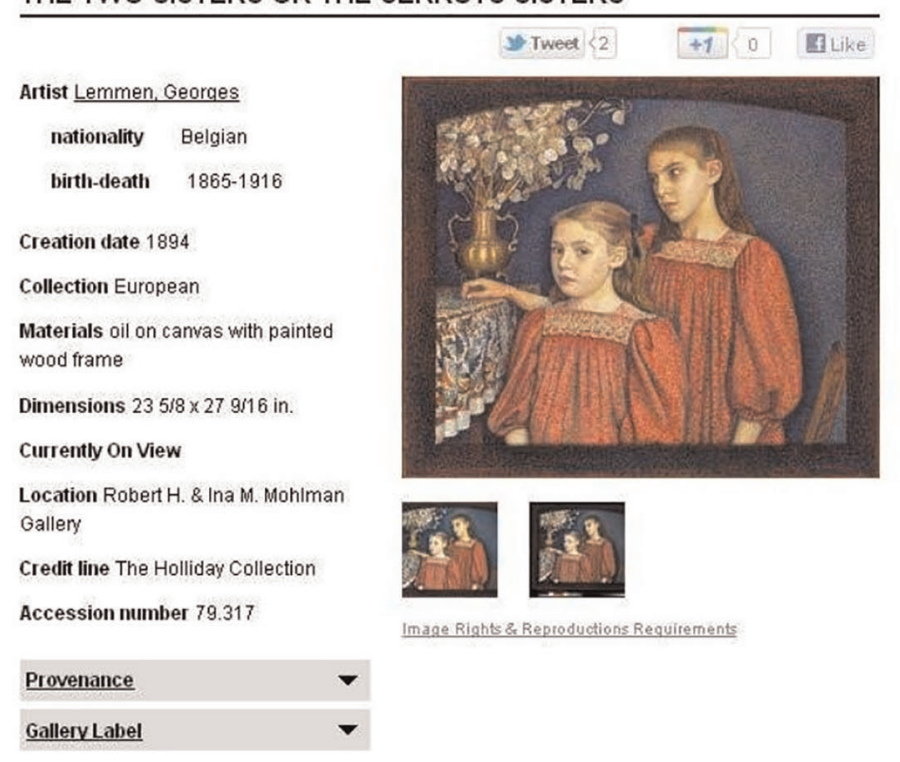

\section{TELL US WHAT YOU SEE}

Login to the Steve Tagger(?) to add tags What Others Saw

blue brassvase chair domestic dots doubleportrait dresses embroideny expression flowers $\mathbf{Q} \mathbf{S}$ matchingdresses moneyplant neoimpressionism paintedframe (0) patternedtablecloth portrait portraits realism red reddresses siblingrivalry Sisters
tablecloth
vase

FIGURE 9. Screen shot, Indianapolis Museum of Art, top of web page, 10 January 2012, documenting The Two Sisters or the Serruys Sisters by Georges Lemmen (oil on canvas with painted wood frame, 1894). Photo credit: Andrew Greg. 
background. ${ }^{60}$ Early in 2012, however, that image had been overshadowed by a differentially weighted tag cloud, headed "What Others Saw," below the invitation, "Tell Us What You See" (fig. 9). According to Greg, the cloud was moved to the bottom of the page later that year; now it is no longer displayed, although individual tags continue to respond to searches. ${ }^{61}$ Was the cloud discarded as a kind of defacement of the painting, an indulgence in graffiti?

In any case, when displayed, such a display could be improved. A heterogenous list of labels below or even next to an image fails to show where in the image these Things are to be found. Almost five centuries ago, Andreas Vesalius managed to connect the label and the location of the depicted Thing in an anatomical image by superimposing index numbers and letters upon it, and transparent overlays can do similar work for illustrations in books. ${ }^{62}$ Image mapping was not built into the steve.museum and Your Paintings Tagger projects. However, the work reported in the next section does incorporate automatic image segmentation so as to identify small objects, a process that could facilitate the highlighting of a tagged detail.

\section{Automatic Tagging}

In his 2014 presentation Greg noted that it was taking volunteer taggers longer than had been anticipated to complete the Your Paintings Tagger project, and he pointed to research undertaken by the Oxford Visual Geometry Group as promising to automate much of the process. Eliot J. Crowley and Andrew Zisserman had collated a subset of already tagged Your Paintings images against labeled photographs mined from the Google Images database, congruent features then being applied to filter the entire Your Paintings database using Convolutional Neural Networks (CNN). The result was a large set of new image tags that were collectively valid to a significant extent but variable in quality. Given a harvest half wheat, half chaff, the Public Catalogue Foundation recruited two hundred fifty experienced taggers to winnow it by hand, a process that in two months yielded almost a million tags that recognized two hundred kinds of things in almost a hundred thousand images; these were added to the Your Paintings database, now Art $U K^{63}$

In 2015 Crowley and Zisserman launched an online "Visual Search of Paintings" tool, which harvests from the Google Images database representative images that have already been tagged for a particular concept (for example, beard); it then extracts significant aspects from them on the fly, using CNN, and applies those aspects as facets to filter the Your Paintings 
database, yielding up to ten thousand images of paintings (and now other works) that might qualify for the tag. ${ }^{64}$ If a search term has already been processed by the system, linked thumbnail images of the paintings will be displayed immediately. If a term is fresh (not already searched), the system will take a few seconds to assemble a set of relevant tagged images from Google Images, displaying thumbnails for them one by one as they are acquired; it will then use that set to filter the Art UK database and display the results-all in less than ten seconds. A trial run on the fresh search term table on 29 January 2021 quickly generated images of ten thousand items in the Art UK collection (mostly paintings, though also some drawings, sculptures, and photographs), many of which indeed showed conspicuous tables, even though they are not yet tagged table: for example, two genre paintings by "Royal Academicians" (tagged as such-the only tag displayed for these paintings): A Difficulty, by Arthur Hacker (1858-1919); and Sunday Morning, by William Edward Stott (1859-1918). ${ }^{65}$ In the latter case the table, though conspicuous, is almost entirely obscured by a tablecloth. Now you see it, now you don't, or vice versa.

The "Visual Search of Paintings" process works well enough for nouns that usually name a single concept, such as horse. It predictably falters with homonyms such as bank, or robust polysemes such as pipe. The forty-six training images of pipe harvested by the system from Google Images included lots of tubular pipes and fewer pipes for tobacco; therefore, only a few of the reported paintings display a pipe suitable for smoking. Such semantic ambiguity presents a problem, one among many, but it is not insuperable. In this as in other respects it will not be surprising if automatic tagging of things in paintings continues to improve. "If a human can do it, a computer should be able to do it," Zisserman is said to have said. ${ }^{66}$ Someday, what the computer sees, is that.

\section{Epilogue}

During the several years in which I have been following the fortunes of the Your Paintings Tagger project, Julia Thomas has led two substantial projects that involve the digitization and display of illustrations that were published in magazines and books, the Database of Mid-Victorian WoodEngraved Illustration, and, more recently The Illustration Archive: Illuminating the Past. ${ }^{67}$ The former was modest in scope, presenting high-resolution scans of wood-engraved illustrations that had been "published in or around 1862." The project editors tagged these images by hand, using terms drawn from a custom-made hierarchical system of descriptive terms. ${ }^{68}$ The Illustration Archive is vastly more ambitious, involving the tagging of more than 
a million book and journal illustrations that had been scanned by Microsoft and were made available by the British Library. Here close editorial curation was out of the question, and crowdsourcing was the first practical resort-to be bolstered later, perhaps, by computer-image annotation. As of 29 January $2021,86,082$ of these images had been tagged, some several times, totaling 186,779 tags. ${ }^{69}$

Professor Thomas's book Nineteenth-Century Illustration and the Digital: Studies in Word and Image (2017) is an often subtle discussion, prompted by practical experience, of the possibilities and pitfalls of verbal tagging of images-whether by experts or crowdsourced amateurs-whether they be images of paintings, illustrations, maps, or decorations. ${ }^{70}$ Many of her incidental observations about the Your Paintings project are helpful supplements to what I report here-for example, that it was constructed in nationalistic terms for British citizens to contribute to the elucidation and celebration of British possessions (73). A notable aspect of the book is its ambivalence about the illustration-annotation projects that it explains and advocates, doomed to inadequacy as any verbal response to a picture must be, because "the illusion of the equivalence of word and image on which both keywords and prose descriptions depend is only ever an illusion: words do not seamlessly map onto pictures. Indeed, in many ways, the activity of tagging is not actually one of 'mapping' at all, but of interpretation" (56).

The same is true of the activity of seeing, or seeing-as. When we say what we see we are at least twice interpreting: thrice when we see pictures, even (pace Stein) oil paintings, and say what it is that we see in them.

\section{Notes}

Thanks are due to Amy Fairgrieve, Lyndel King, and Thomas Habersatter for advice.

1. Andrew Ellis et al., "Your Paintings: A Nation's Oil Paintings Go Online, Tagged by the Public," Museums and the Web 2012, 25 March 2012, https:// www.museumsandtheweb.com/mw2012/papers/your_paintings_a_nation_s_ oil_paintings_go_onl.html; Internet Archive, 6 December 2013, https://web. archive.org/web/20131206184035/https://www.museumsandtheweb.com/ mw2012/papers/your_paintings_a_nation_s_oil_paintings_go_onl.html.

2. Your Paintings Tagger (blog), August 2015, http://tagger.thepcf.org.uk/; Internet Archive, 13 August 2015, https://web.archive.org/web/20150813091138/ http:/ / tagger.thepcf.org.uk.

3. Kathryn Eccles and Andrew Greg, "Your Paintings Tagger: Crowdsourcing Descriptive Metadata for a National Virtual Collection," in Crowdsourcing Our Cultural Heritage, ed. Mia Ridge (Farnham, UK, 2014), 190.

4. Ibid., 191. 
5. Zooniverse: Real Science Online (blog), 2009, http://zooniverse.org/; Internet Archive, 15 December 2009, https://web.archive.org/web/20091215143635/ http://zooniverse.org.

6. Robert Simpson, Kevin R. Page, and David De Roure, "Zooniverse: Observing the World's Largest Citizen Science Platform," in WWW'14 Companion: Proceedings of the 23rd International Conference on World Wide Web (New York, 2014), 1049, https://doi.org/10.1145/2567948.2579215.

7. AnnoTate (blog), https://anno.tate.org.uk.

8. Fishing in the Past (blog), Research, https://www.zooniverse.org/projects/ anneoverduin/fishing-in-the-past/about/research; Fishing in the Past Statistics, https://www.zooniverse.org/projects/anneoverduin/fishing-in-the-past/ stats.

9. Andrew Greg, "Engaging the Public in Tagging and Researching the UK's Paintings: Two Case Studies," presentation for the "Scotland's Collections and the Digital Humanities" knowledge-exchange project, University of Edinburgh, 12 September 2014. Slides at Slideshare, https:/ /www.slideshare.net/tarastar/ engaging-the-public-in-tagging-and-researching-the. Video at Vimeo, https:// vimeo.com/112328733.

10. Jennifer Trant, Tagging, Folksonomy and Art Museums: Results of steve.museum's Research, 31 January 2009, 58-59, Digital Library of Information Science \& Technology, University of Arizona, http://hdl.handle.net/10150/105627.

11. Art UK (blog), "Tag Artworks: Temporary Suspension," https://artuk.org/ participate/tag-artworks; Internet Archive, 25 June 2016, https://web.archive. org/web/20160625185800/https:/artuk.org/participate/tag-artworks.

12. Art UK, "Tagger," https://artuk.org/about/tagger; Internet Archive, 17 November 2019, https://web.archive.org/web/20191117193718/https:// artuk.org/about/tagger\#.

13. Your Paintings Tagger, "1 of 4 paintings-Trial," http://tagger.thepcf.org.uk/ tutorial; Internet Archive, 16 August 2014, https://web.archive.org/web/ 20140816091835/http://tagger.thepcf.org.uk/tutorial. Ellis et al., "Your Paintings."

14. Your Paintings Tagger, "Frequent questions," http://tagger.thepcf.org.uk/faq/ 1175; Internet Archive, 16 August 2014, https://web.archive.org/web/ 20140816050754/http://tagger.thepcf.org.uk/faq/1175.

15. Michel Foucault, "Ceci n'est pas une pipe," trans. Richard Howard, October 1 (Spring 1976): 13, 14, https://doi.org/10.2307/778503. Translated (except for the title) from "Ceci n'est pas une pipe," Cahiers du chemin 2 (January 1968): 93.

16. "Current Tags" for René Magritte, The Treachery of Images (This is Not a Pipe) (La trahison des images [Ceci nest pas une pipe]), http:/ / collections.lacma.org/node/ 239578 (tags revealed by clicking on the "Tag" tab). The full tag set was published after 9 December 2013 and by 16 March 2014; Internet Archive, https:/ / web.archive.org/web/2020*/https://collections.lacma.org/node/239578.

17. E. H. Gombrich, Art and Illusion: A Study in the Psychology of Pictorial Representation, 2nd ed. (Princeton, 1961), 115.

18. Ibid., 414, citing Henri Matisse, "Notes d'un peintre sur son dessin," Le Point 4, no. 21 (1939): 14 (original emphasis).

19. Matisse on Art, ed. Jack D. Flam (London, 1973), 82.

20. Matisse on Art, ed. Jack D. Flam, 2nd ed. (Berkeley, 1995), 132, 285.

21. Gertrude Stein, Lectures in America (New York, 1935), 74-75. I was led to this passage by Franklin R. Rogers and Mary Ann Rogers, who confirm Stein's notion of "the reality of the oil painting as oil painting" by quoting the Matisse 
anecdote after Gombrich; Franklin R. Rogers and Mary Ann Rogers, Painting and Poetry: Form, Metaphor, and the Language of Literature (Lewisburg, PA, 1985), 105.

22. E. H. Gombrich, Art and Illusion: A Study in the Psychology of Pictorial Representation, Millennium Edition (Princeton, 2000), xxv-xxx.

23. Nelson Goodman, Languages of Art: An Approach to a Theory of Symbols (Indianapolis, 1968).

24. E. H. Gombrich, "Image and Code: Scope and Limits of Conventionalism in Pictorial Representation," in Image and Code, ed. Wendy Steiner (Ann Arbor, 1981), 11-42. Reprinted in E. H. Gombrich, The Image and the Eye: Further Studies in the Psychology of Pictorial Representation (Oxford, 1982), 278-97. See also Michael Hancher, "Definition and Depiction," Word E Image 26 (2010): 26062, https:/ / doi.org/10.1080/02666280903270360.

25. Charles H. Caffin, How to Study the Modern Painters (London, 1914), 213, 210.

26. Charles H. Caffin, "Henri Matisse and Isadora Duncan," Camera Work 25 (1909): 17; referencing George Beeson, "Pictorial Photography: A Series of Interviews," Camera Work 24 (1908): 22.

27. John Dewey, Art as Experience (1934), in The Later Works, 1925-1953, ed. Jo Ann Boydston and Harriet Furst Simon (Carbondale, IL, 1981-90), 10:113-14; A. C. Bradley, "Poetry for Poetry's Sake," Oxford Lectures on Poetry, 2nd ed. (London, 1909), 3-34.

28. Dewey, Art as Experience, in Later Works, 10:117-18. As Boydston and Simon suggest in their editorial notes (10:358), Dewey probably derived the anecdote from Matisse's patron Albert C. Barnes-to whom Dewey dedicated Art as Experience. The painting in question has not been identified; a plausible candidate is Seated Nude in a Tan Room (1918; Barnes Foundation, Philadelphia).

29. Jacques Derrida, The Truth in Painting, trans. Geoff Bennington and Ian McLeod (Chicago, 1987), 293. For a contextualization of Derrida's remarks on Martin Heidegger and Vincent van Gogh see C. Oliver O'Donnell, Meyer Schapiro's Critical Debates: Art Through a Modern American Mind (University Park, PA, 2019), 142-62.

30. Ronald Paulson, Hogarth: His Life, Art, and Times, ed. Anne Wilde (New Haven, 1974), 223; Ronald Paulson, The Art of Hogarth (London, 1975), 141.

31. The collaborating institutions were Denver Art Museum, Guggenheim Museum, the Cleveland Museum of Art, Indianapolis Museum of Art, Los Angeles County Museum of Art (which owns Magritte's painting La trahison des images), the Metropolitan Museum of Art, Minneapolis Institute of Arts, the Rubin Museum of Art, San Francisco Museum of Modern Art, Archives \& Museum Informatics, and Think Design; Trant, Tagging, Folksonomy, and Art Museums, 7.

32. Judith L. Klavans, Rebecca LaPlante, and Jennifer Golbeck, "Subject Matter Categorization of Tags Applied to Digital Images from Art Museums," JASIST: Journal of the Association for Information Science and Technology 65 (2014): 4, https://doi.org/10.1002/asi.22950.

33. Sara Shatford, "Analyzing the Subject of a Picture: A Theoretical Approach," Cataloging Eं Classification Quarterly 6, no. 3 (Spring 1986): 42-48, https://doi. org/10.1300/J104v06n03_04.

34. Erwin Panofsky, Studies in Iconology: Humanistic Themes in the Art of the Renaissance (New York, 1939), 5, emphases in original. Of course not all details of preiconographical description will be certain or unambiguous; a hawk may be mistaken for a handsaw, especially if depicted in a cubist painting. For a useful 
meditation on such difficulty see Mark Roskill, "On the Recognition and Identification of Objects in Paintings," Critical Inquiry 3 (1977): 677-707, https:// www.jstor.org/stable/1343056.

35. William T. Ivins, Prints and Visual Communication (Cambridge, MA, 1939), 2, 146, 177; Wolfgang M. Freitag, "Early Uses of Photography in the History of Art," Art Journal 39 (1979-80): 117-23; Art History through the Camera's Lens, ed. Helen E. Roberts (London, 1995).

36. Flickr, The Commons, "Participating Institutions," https://www.flickr.com/ commons/institutions; Jason Vaughan, "Insights Into The Commons on Flickr," portal: Libraries and the Academy 10 (2010): 185-214, https://doi.org/ 10.1353/pla.0.0095; George Oates, "Social Structures for Online Images," presentation, November 2011, video, UMedia, University of Minnesota Libraries, https://lib-umedia-prd-01.oit.umn.edu/item/p16022coll262:172.

37. Leo Spitzer, "The 'Ode on a Grecian Urn,' or Content vs. Metagrammar," Comparative Literature 7 (1955): 203-25, https://www.jstor.org/stable/ 1768227. According to Ruth Webb, "It was the prodigiously learned and inventive Spitzer who ... coined" the modern sense of the term discussed here; Ruth Webb, "Ekphrasis Ancient and Modern: The Invention of a Genre," Word $\mathcal{E}^{\circ}$ Image 15 (1999): 10, https://doi.org/10.1080/02666286.1999.10443970. See also her book Ekphrasis, Imagination and Persuasion in Ancient Rhetorical Theory and Practice (Farnham, UK, 2009), 33-38. For an earlier critique of anachronistic deployment of the term see Raymond A. Macdonald, "Ekphrasis, Paradigm Shift, and Revisionism in Art History," RES: Anthropology and Aesthetics 21 (1993): 112-23, https://www.jstor.org/stable/20166883.

38. Svetlana Leontief Alpers, "Ekphrasis and Aesthetic Attitudes in Vasari's Lives," Journal of the Warburg and Courtauld Institutes 23 (1960): 190, https:/ /www.jstor. org/stable/750591.

39. OED Online, s.v. “tag, n.1,” https://www.oed.com/view/Entry/197010.

40. Jesse James Garrett, "An Interview with Flickr's Eric Costello," adaptive path (blog), 4 August 2005, https://www.adaptivepath.com/ideas/e000519; Internet Archive, 15 April 2011, https://web.archive.org/web/20110415073428/ https://www.adaptivepath.com/ideas/e000519.

41. John Sayers, "The Library of Congress and Flikr: A Photo Dialogue," LCM: Library of Congress Magazine 2, no. 2 (March-April 2013): 8-9; "National Gallery Goes Online," The National Gallery (blog), 23 June 2011, https://www. nationalgallery.org.uk/about-us/press-and-media/press-releases / nationalcollection-goes-online.

42. OED Online, s.v. "tag, n.1."

43. City as Canvas: New York City Graffiti from the Martin Wong Collection, ed. Sean Corcoran and Carlo McCormick (New York, 2013).

44. Matthew Arnold, On Translating Homer (London, 1861), 64; Matthew Arnold, Essays in Criticism (London, 1865), 1, 6.

45. Dewey, Art as Experience, in Later Works, 10:117, quoting Bradley, "Poetry for Poetry's Sake," 10.

46. Andrew Ellis et al., Oil Paintings in Public Ownership in North Yorkshire (London, 2006), 91 (thumbnail image), 377. This catalog reports a longer title: Still Life with Grapes, Oysters, a Lemon and Pomegranates on a Draped Table.

47. The painting was one of many images returned by a search on pipe at http:// www.bbc.co.uk/arts/yourpaintings (a URL since retired). By 18 January 2021 the display of tags, now at Art UK, https://www.artuk.org/discover/artworks/ still-life-with-a-lobster-and-oysters-9931, was much the same, although with Meal 
added, and Still life gone, leaving Still Life in possession; and now alphabetized, with statistics added, ranging from 2 (Oystershell) to 3,091 (Table). A new note explains, "The tags above come from the public, and also from an image recognition project run by the Visual Geometry Group, University of Oxford." That project is discussed later in this essay.

48. The designers favored the singular form of nouns only, fearing that the less common plural form would subtract from the statistical presence of the underlying term (Eccles and Greg, "Your Paintings Tagger," 192); but evidently both forms were accepted.

49. Ellis et al., Oil Paintings in Public Ownership in North Yorkshire, 91.

50. Lisa Howard, "Still Life with Grapes, Oysters and a Lemon," National Inventory of Continental European Paintings (NICE Paintings), VADS, University for the Creative Arts, https://www.vads.ac.uk/digital/collection/NIRP/id/32476/ $\mathrm{rec} / 3$. The NICE documentation project ran from 2003 to 2015.

51. "19th century? by 'v. Schut', (signed as such), oil on canvas, 49,5 x $63 \mathrm{~cm}$, Sale Berne, Dobiaschofsky, 6 November 2015, lot 387 (sold CHF 2000)"; Fred G. Meijer, Jan Davidsz. de Heem, 1606-1684, (PhD diss., University of Amsterdam, 2016), 2:74. The guess at the date may be in the auction catalog, which I have not seen. Meijer notices this additional copy (though not the one at the Craven Museum) in his detailed account of the original painting by de Heem, which is discussed later in the essay.

52. "Die glimmende Zündschnur, die Pfeife oder der umgestürzte Römer...gemahnen an die Vergänglichkeit allen irdischen Lebens und sind daher Vanitas-Symbole"; Gabriele Groschner, Thomas Habersatter, and Erika Mayr-Oehring, Meisterwerke: Residenzgalerie Salzburg (Salzburg, 2002), 19.

53. For example, Jan Jansz. van de Velde III, Still Life with a Pipe and Taper (1653); plate 18 in Fred G. Meijer, The Collection of Dutch and Flemish Still-life Paintings Bequeathed by Daisy Linda Ward (Zwolle, Netherlands, 2003); also as Still Life with a Pipe-Lighter, at Art UK: https://artuk.org/discover/artworks/still-life-with-apipe-lighter-142873. "The glowing fuse is a well-known vanitas attribute," Sam Segal remarked apropos the de Heem painting; A Fruitful Past: A Survey of the Fruit Still Lifes of the Northern and Southern Netherlands From Brueghel till Van Gogh, trans. P. M. van Tongern-Woodland ([Amsterdam?], 1983), 72.

54. "'All seeing is seeing as.' In other words, if a person sees something at all it must look like something to him"; G. N. A. Vesey, "Seeing and Seeing As," Proceedings of the Aristotelian Society, n.s., 56 (1955-56): 114, https://www.jstor.org/stable/ 4544559. "All seeing is 'seeing-as,' and it must be so because of the intentionality of the visual experience"; John R. Searle, Seeing Things as They Are: A Theory of Perception (Oxford, 2015), 74.

55. John R. Searle, "A Classification of Illocutionary Acts," Language in Society 5 (1976): 1-23, https://www.jstor.org/stable/4166848. For a wide-ranging account of the necessity and difficulties of description, see Sharon Marcus, Heather Love, and Stephen Best, "Building a Better Description," Representations 136 (2016): 1-21, https://doi.org/10.1525/rep.2016.135.1.1.

56. Paul Grice, Studies in the Way of Words (Cambridge, MA, 1989), 26.

57. Linda Zajac, "Social Metadata Use in Art Museums: The Case of Social Tagging," PNLA Quarterly 77, no. 2 (Winter 2013): 69; Greg, "Engaging the Public."

58. “Waves, Gustave Courbet, French, 1819-1877," Philadelphia Museum of Art, https://philamuseum.org/collections/permanent/104430.html. Dozens of changes to this web page, including changes to social tagging, ranging from 
6 January 2007 to 27 February 2019, can be explored at https://web.archive. org/web/2019*/https://www.philamuseum.org/collections/permanent/ 104430.html. The most recent configuration of the page, now at https://www. philamuseum.org/collection/object/104430, eschews social tagging altogether-apparently in keeping with a general change of policy that took effect early in 2021. The Philadelphia Museum of Art also owns another painting by Courbet with the same title.

59. "Waves, Gustave Courbet, French, 1819-1877," Philadelphia Museum of Art, https://www.philamuseum.org/collections/permanent/104430.html; Internet Archive, 14 February 2014, https://web.archive.org/web/ 20140214113032/https://www.philamuseum.org/collections/permanent/ 104430.html.

60. Georges Lemmen, The Two Sisters or The Serruys Sisters, Indianapolis Museum of Art, http://collection.imamuseum.org/artwork/79200.

61. Greg, "Engaging the Public," slide 10. As of 29 January 2021 the search engine at http:/ / collection.imamuseum.org offers a general, undefined search option, and then, after a search returns results, the ability to refine results by one or another facet: Collection Area / Artist/Maker / Materials / Object Type / Technique / Colors. Although there is no facet for Thing, a general search s.v. tablecloth will yield twenty results, including The Two Sisters.

62. Andreas Vesalius, De humani corporis fabrica (Basel, 1555).

63. Greg, "Engaging the Public," slide 21; Rachel Collings, "The Art of Computer Recognition," Art UK, 1 February 2015, https://artuk.org/about/blog/the-artof-computer-recognition; Internet Archive, 21 March 2019, https://web. archive.org/web/20190321113238/https:/artuk.org/about/blog/the-art-ofcomputer-recognition; Elliot J. Crowley and Andrew Zisserman, "In Search of Art," Computer Vision-ECCV 2014 Workshops: Zurich, Switzerland, September 6-7 and 12, 2014, Proceedings Part I, ed. Lourdes Agapito, Michael M. Bronstein, and Carsten Rother (Cham, Switzerland, 2015), 54-70, https://doi.org/10.1007/ 978-3-319-16178-5_4; Elliot J. Crowley and Andrew Zisserman, "The State of the Art: Object Retrieval in Paintings Using Discriminative Regions," Proceedings of the British Machine Vision Conference 2014, ed. Michel Valstar, Andrew French, and Tony Pridmore (2014), http://dx.doi.org/10.5244/C.28.38.

64. Elliot J. Crowley and Andrew Zisserman, "Visual Search of Paintings," Visual Geometry Group, Department of Engineering Science, University of Oxford, http://www.robots.ox.ac.uk/vgg/research/art_search/; Internet Archive, 18 February 2015, https://web.archive.org/web/20150218042224/http:/www. robots.ox.ac.uk/vgg/research/art_search. For technical details see note 63; also Elliot J. Crowley and Andrew Zisserman, "The Art of Detection," Computer Vision: ECCV-2016 Workshops: Amsterdam, The Netherlands, October 8-10 and 15-16, 2016, Proceedings, Part I, ed. Gang Hua and Hervé Jégou (Cham, Switzerland, 2016), 721-37, https://doi.org/10.1007/978-3-319-46604-0_50. Ernesto Coto joined Crowley and Zisserman as a co-author of the "Visual Search of Paintings" site; I owe him thanks for help with a transient access problem.

65. "A Difficulty, Arthur Hacker (1858-1919), Gallery Oldham," Art UK, https:// artuk.org/discover/artworks/a-difficulty-90623; "Sunday Morning, William Edward Stott (1859-1918), Manchester Art Gallery," Art UK, https://artuk. org/discover/artworks/sunday-morning-206136. For the Scott painting, a quoted museum label does include the term dining table, which functions as a de facto tag and responds to a search request.

66. Collings, "The Art of Computer Recognition." 
67. Database of Mid-Victorian Wood-Engraved Illustration, https://www.dmvi.org. uk; The Illustration Archive, https://illustrationarchive.cf.ac.uk.

68. "Iconographic Description in DMVI," Database of Mid-Victorian WoodEngraved Illustration, http://www.dmvi.cf.ac.uk/guide/iconography.html.

69. The Illustration Archive, statistics page, https://illustrationarchive.cf.ac.uk/ stats.

70. Julia Thomas, Nineteenth-Century Illustration and the Digital: Studies in Word and Image (Cham, Switzerland, 2017). 